\title{
THE UNITY OF THE CHURCH IN ACTS IN ITS LITERARY SETTING ${ }^{1}$
}

\begin{abstract}
Alan J. Thompson
This thesis examines the Lukan themes of unity and disunity against ancient Greco-Roman and Jewish social and political discourses on concord and discord, in order to better understand the context in which Luke highlights the themes of unity and disunity. The themes of unity and disunity are particularly prominent in ancient discussions concerning the reigns of rulers, the evaluation of laws/constitutions/forms of government, and in descriptions of the contrasting effects of unity and disunity in the destruction and preservation of peoples and cities. These themes were grouped under the broad categories of kingship and law (chapters two and three), and the preservation and destruction of cities (chapters four and five). In the context of its literary setting, the theme of the unity of the church in Acts contributes to Lukan christological claims that Christ is the true King, and Lukan ecclesiological claims that the Christian community is the true people of God.

Following an initial survey highlighting the importance of the themes of unity and disunity in Acts, chapter one surveys the literature on these themes and observes that discussion has largely revolved around Luke's account of events such as the Jerusalem Council; the historical reliability of the portrait of Paul in Acts; Paul's relationship with Peter and with the Jerusalem church; and the portrait of the Jews. Thus, chapter one argues that there is a need for a detailed study of the theme of the unity of the church in Acts that relates this theme to: (a) the wider narrative references to discord and disunity in Acts; and (b) Greco-Roman and Jewish discussions of unity and disunity.
\end{abstract}

1 Alan J. Thompson, 'The Unity of the Church in Acts in its Literary Setting' (Ph.D. thesis, Trinity Evangelical Divinity School, 2004) Supervisor: Dr David W. Pao. This thesis is due to be published in the Library of New Testament Studies series by T\&T Clark International. 
Chapter two focuses on the themes of kingship and law in ancient discussions of unity. It argues, firstly, that homonoia is frequently associated with the subject of kingship and is frequently the means for evaluating kings and their reign. Roman emperors in particular are both praised and criticised for their ability or failure to bring concord (e.g., Virgil, Eclogae 4:4-17; Polybius, Historiae 6:11-18). The Old Testament and Jewish second-temple writers also frequently combine these themes. The unity of God's people under the reigns of David and Solomon is the pattern for the expectation that unity would be restored under a coming king (Ezek. 34:22-23; 37:15-28). Secondly, chapter two argues that the theme of unity is also closely associated with the subject of law and the best form of government. Constitutions, laws, law-makers, and forms of government are frequently evaluated according to the presence of unity or discord. The works of Plato and Aristotle are prominent examples of the close association between the themes of unity and disunity, and the theme of law, in their evaluations of the 'best' constitutions - often using language common to Acts (e.g., Plato, Respublica 462-466; Aristotle, Politica 2:1:3). Josephus (especially in Against Apion) particularly emphasises the themes of unity and law in an apologetic for the Jewish people.

Chapter three argues that the theme of unity also features in contexts in which the themes of kingship and law are prominent in Acts. The emphasis on the kingship of Jesus and his reign from the throne of David in Acts 2 is placed together with an emphasis on the unity of his people in common submission to his lordship. The importance of unity in ancient Roman imperial claims suggests a plausible context for the juxtaposition of christological claims for the kingship of Jesus and ecclesiological claims for the unity of his people in the book of Acts. The emphasis on Jesus' kingship and his unifying reign, particularly in Acts 2, suggests that it is possible to move beyond the traditional debates over Luke's 'ecclesial' or 'political' apologetic, to note the claims for Christ in contrast to the Roman emperor (as already intimated in Luke 2:1-14). This chapter also highlights the prominence of the connection between pneumatology and the theme of unity - a neglected aspect in studies of Lukan pneumatology. When placed together with Lukan Christology, the unifying role of the Spirit is seen as part of the reign of the risen Lord Jesus. Previous studies have focused on the role of the Spirit in empowering and guiding Christians in Acts. 
This study shows that there is a consistent emphasis in the narrative of Acts on the role of the Spirit in uniting the people of God.

Chapter three also argues that the Sinai parallels in Acts 2 draw attention to the combination of the themes of law and unity in Acts (cf. also Philo, De Decalogo 36-43). The description of the unity of the Christian community is found in contexts that recall Hellenistic discussions of the 'best constitution/body of laws/form of government' - in contexts where the law is fulfilled, and in contexts where aspects of the law have been set aside (e.g., Acts 4:32-34; 6:1-7; 10:1-11:18; 15:1-35). Thus, Luke's ecclesiological argument includes the point that it is in the Christian community that the law is fulfilled, and that this 'new constitution' under the reign of the Lord Jesus and the teaching of his authorised delegates, the apostles, brings true unity and is (in the language of some ancient discussions of unity) the 'best' community, in contrast with competing claims and constitutions. That is, they are the true people of God.

Chapter four returns to a study of Greco-Roman and Jewish literature and notes the prominence of the themes of unity and disunity in descriptions of the preservation and destruction of peoples and cities (especially in historians such as Herodotus, Thucydides and Josephus, and in the political discourses of authors such as Cicero, Plutarch, Dio Chrysostom, and later, Aelius Aristides). The devastating effects of discord are frequently highlighted. Discord is often described as the reason for defeat in war and as characteristic of ruined and destroyed cities. Unity, however, is often seen as the greatest of blessings; the means for the preservation of cities; and the reason for the rise and victory of kings and nations.

Chapter five builds on the work of those who have highlighted the theme of conquest in the progress of the Word in Acts. ${ }^{2}$ The presence of the themes of unity and disunity in the same contexts as the theme of the conquest of the Word in the midst of opposition further contributes to the Lukan ecclesiological claim for the church as the community of the Word. Previous studies have limited their focus on the 'riot scenes' to the issue of the 'harmlessness' of the church. Lukan terminology, however, frequently resembles ancient descriptions of disorder, dis-

2 Cf. David W. Pao, Acts and the Isaianic New Exodus, WUNT 2.130 (Tübingen: Mohr Siebeck, 2000): 150-167. Cf. also Daniel Marguerat, The First Christian Historian: Writing the 'Acts of the Apostles' (Cambridge: Cambridge University Press, 2002): 231-56. 


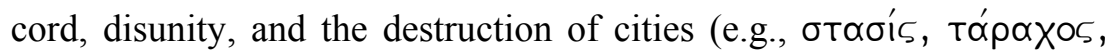
Өópußo5). Thus, ancient discussions of the devastating effects of discord in contrast to unity provide a plausible context for the accounts of 'riot scenes' in Acts. Luke associates this language of discord and disunity with the cities of Iconium, Thessalonica, Ephesus, and Jerusalem (e.g., Acts 14:4; 17:5, 8; 19:23, 29, 32, 40; 20:1; 21:30-31, 34). The Christian community, however, is frequently described in these same contexts in language that highlights its common submission to the one Lord Jesus. The unity of the Christian community in the context of the disunity of those opposed to the Lord Jesus, therefore, contributes to the claim that it is the community of the conquering Word - the true people of God.

The final chapter relates the conclusions of the previous chapters to the issue of historical plausibility and idealisation. This chapter notes that, in light of the location of the theme of unity in the context of historical realities in ancient literature, it is unwarranted to assume that Luke is idealising just because the theme of unity is present (e.g. Aristotle, Pol. 2:6). Furthermore, the idea that Luke is merely idealising is rendered unlikely in light of the use of similar language to describe opposition to the Christian community, and the presence of disagreements among believers in Acts. The references to 'united opposition', and disagreements among believers, point to Luke's primary focus on the true unity of one people in common submission to the one Lord Jesus, rather than on uniformity. Unlike some ancient discussions of unity, Luke does not emphasise the importance of unity in and of itself, or as an abstract ideal. Luke argues that because the risen Lord Jesus has ascended and reigns from the throne at the right hand of God, the common submission to the Lord Jesus that characterises the Christian community is true unity. The soteriological unity that comes from common submission to Christ's lordship can be expressed in relational unity as believers submit to the lordship of Jesus and the leadership of the apostles as his 'authorised delegates'.

The conclusions of this thesis have implications for Lukan theology in the areas of Christology, pneumatology, the role of the law, and ecclesiology. The prominence of the theme of unity in combination with the theme of kingship in ancient literature, and the evidence for this in Acts, indicates that the unity of his people and the role of the Lord Jesus in bringing about this unity contribute to the christological argument that Jesus is the true King. This study also indicates that the 
theme of unity must be considered when examining Lukan Christology in the context of Roman imperial claims. Also neglected in Lukan studies is the combination of the themes of unity and the law in Acts in the context of Luke's ecclesiological argument. Luke's ecclesiological argument includes the point that it is in the Christian community that the law is fulfilled, and that this 'new constitution' under the reign of the Lord Jesus brings true unity in contrast to competing claims. Building on the pervasive descriptions in ancient literature of the contrasting effects of unity and disunity (particularly the terminological similarities to Acts in the destructive effects of discord), this study provides a fresh analysis of the narrative contexts of opposition to the conquest of the Word, which further suggests that the themes of unity and disunity contribute to the Lukan argument that the Christian community is the true people of God. 